\title{
BUBR1 expression in benign oral lesions and squamous cell carcinomas: Correlation with human papillomavirus
}

\author{
RÉGIA C.P. LIRA ${ }^{1}$, FABIANA A. MIRANDA ${ }^{1}$, MÁRCIA C.M. GUIMARÃES ${ }^{1}$, RENATA T. SIMÕES ${ }^{4}$, \\ EDUARDO A. DONADI ${ }^{2}$, CHRISTIANE P. SOARES ${ }^{3}$ and EDSON G. SOARES ${ }^{1}$
}

\begin{abstract}
${ }^{1}$ Departamento de Patologia, Faculdade de Medicina de Ribeirão Preto, Universidade de São Paulo-USP, Av. Bandeirantes, 3900, CEP: 14049-900; ${ }^{2}$ Divisão de Imunologia Clínica, Departamento de Clínica Médica, Faculdade de Medicina de Ribeirão Preto, Universidade de São Paulo-USP, Av. Bandeirantes, 3900 (6º andar do HC), CEP: 14048-900;

${ }^{3}$ Departamento de Análises Clínicas, Faculdade de Ciências Farmacêuticas de Araraquara, Universidade Estadual Paulista Júlio de Mesquita Filho-UNESP, Rua Expedicionários do Brasil, 1621, CEP: 14801902, Centro, Araraquara-SP;

${ }^{4}$ Núcleo de Pós-Graduação e Pesquisa, Santa Casa de Belo Horizonte, Av. Francisco Sales, 1111 Ala D $9^{\circ}$ andar, Santa Efigênia, CEP: 30150-22, Belo Horizonte-MG, Brazil
\end{abstract}

Received October 30, 2009; Accepted December 9, 2009

DOI: $10.3892 /$ or_00000729

\begin{abstract}
Oral squamous cell carcinoma (OSCC) is the most common head and neck cancer. Only in Brazil, the estimate is for 14,160 new cases in 2009. HPV is associated with increasing risk of oral cancer, but its role in carcinogenesis is still controversial. BUBR1, an important protein in the mitotic spindle assembly checkpoint (SAC), has been associated with some virus-encoded proteins and cancer. The aim of the present study was to evaluate the expression of BUBR1 in non-malignant oral lesions and OSCC with and without metastasis associated with HPV infection. We performed immunohistochemistry for BUBR1 in 70 OSCC biopsies divided into three groups (in situ tumors, invasive tumors without metastasis and invasive tumors with metastasis) with their respective lymph nodes from samples with metastasis and in 16 non-malignant oral lesions. PCR was performed in order to detect HPV DNA. Significantly higher BUBR1 expression associated with shorter survival $(\mathrm{p}=0.0479)$ was observed in malignant lesions. There was also a significant correlation $(\mathrm{r}=1.000)$ with BUBR 1 expression in lesions with metastasis and their lymph nodes. Ninety percent of OSCC and 100\% of benign lesions were HPV positive. HPV16 and HVP18 were present in 13 and 24\% of HPV-positive OSCC samples, respectively. HPV was more prevalent $(76 \%)$ in samples with a high BUBR1 expression and the absence of viral DNA had no influence
\end{abstract}

Correspondence to: Dr Edson Garcia Soares, Departamento de Patologia, Faculdade de Medicina de Ribeirão Preto, Universidade de São Paulo-USP, Avenida Bandeirantes, 3900, CEP: 14049-900, Ribeirão Preto, SP, Brazil

E-mail: egsoares@fmrp.usp.br

Key words: BUBR1, HPV, oral squamous cell carcinoma on BUBR1 expression. These findings suggest that HPV could be associated with overexpression of BUBR1 in OSCC, but not in benign oral lesions.

\section{Introduction}

Oral squamous cell carcinoma (OSCC) is the most common head and neck cancer and occupies the eighth position in cancer incidence worldwide, with an estimated annual incidence of more than 170,000 new cases (1-3). Only in Brazil, the estimate is for 14,160 new cases in 2009 (4). OSCC is a disease particularly occurring in low income communities and among older men, with a mean age at diagnosis of 62.0 years and a male:female ratio between 1.3:1 and 2:1 (5).

Tobacco and/or alcohol are recognized as the major risk factors associated with oral carcinogenesis, but several studies have shown that human papillomavirus (HPV) is associated with increasing risk of oral cancer, independently of exposure to tobacco and alcohol (6-9). The role of HPV in oral carcinogenesis is still controversial because of different frequencies detected $(0-100 \%)(10,11)$. Some studies report more prevalence of high-risk HPV types 16 and 18 in malignant and potentially malignant oral lesions, but other authors have not detected an association between these types of HPV and the type of oral lesion (12-16).

The oncoproteins E6 and E7 from HPV can be viewed as oncogenic factors which can disrupt checkpoint controls and interfere in major control pathways of cell cycle and apoptosis, thereby inducing mitotic abnormalities and increasing genomic instability (17). Some studies show that karyotypes of OSCC are near-triploid and present many structural and numerical abnormalities that could influence chromosomal segregation $(6,18-20)$. BUBR1 is an important protein in the mitotic spindle assembly checkpoint (SAC), a checkpoint that protects the cell from chromosome missegregation and aneuploidy during mitosis. Individuals with missense or truncating mutations in the BUBR1 gene are predisposed to 
the development of childhood cancer including rhabdomyosarcoma, Wilms tumor, and leukemia (21). However, BUBR1 mRNA and/or protein overexpression has been found to be associated with tumor recurrence and progression of renal and bladder cancer $(22,23)$, and was also observed in malignant salivary gland tumors and in breast and gastric cancer (24-26).

Since HPV has been cited as a risk factor of oral carcinogenesis, and since some studies have shown the association between viral proteins and the BUBR1 $(22,27)$, the aim of the present study was to evaluate the expression of BUBR1 immunoperoxidase in non-malignant oral lesions and in OSCC with and without metastasis associated with HPV infection. An additional objective was to compare quantitative analyses of BUBR1 performed with a computer-assisted system to quantification by a pathologist.

\section{Materials and methods}

Specimens. Eighty-six biopsies of oral lesions were selected from the archives of the Pathology Department, School of Medicine of Ribeirão Preto, University of São Paulo (USP), Brazil. The study was approved by Research Ethics Committee of HCFMRP-USP, project number 9802/07. We selected 16 non-malignant oral lesions $\left(\mathrm{OL}^{\mathrm{NM}}\right), 20$ in situ oral squamous cell carcinomas (OSCC ${ }^{\mathrm{IS}}$ ), 27 invasive oral squamous cell carcinomas without metastases (OSCC ${ }^{\mathrm{WT}}$ ) and 23 invasive oral squamous cell carcinomas with metastases $\left(\mathrm{OSCC}^{\mathrm{W}}\right)$. In addition, 23 cervical lymph nodes (LN) from the patients with $\mathrm{OSCC}^{\mathrm{W}}$ were also evaluated. Thin $(5 \mu \mathrm{m})$ sections were cut, placed on organosilane-pretreated slides and submitted to immunohistochemical assays (BUBR1). Additionally, two sections of $10 \mu \mathrm{m}$ were cut for DNA extraction and HPV typing. Clinicopathological information on the patients such as age, sex, history of smoking and alcohol consumption was obtained from the patients' medical records.

Immunohistochemistry for BUBR1. Immunohistochemistry was performed for the detection of BUBR1 protein using the avidin-biotin peroxidase complex (ABC) method (Novocastra, Newcastle-upon-Tyne, UK). Paraffin-embedded sections were deparaffinized in xylene and then rehydrated through a graded alcohol series. For antigen retrieval, the sections were immersed in Tris-EDTA buffer, $\mathrm{pH}$ 9.0, and submitted to steam heating for $35 \mathrm{~min}$ at $98^{\circ} \mathrm{C}$. The sections were cooled at room temperature and incubated for $20 \mathrm{~min}$ in a $3 \% \mathrm{H}_{2} \mathrm{O}_{2}$ solution to block endogenous peroxidase activity. After rinsing 3 times in $1 \mathrm{M}$ standard phosphate-buffered saline (PBS) baths, the sections were incubated in $2 \%$ horse serum for $30 \mathrm{~min}$ to reduce non-specific antibody binding and with a primary antibody raised against BUBR1 overnight (Mouse monoclonal, 1:100; Abcam-ab54894, Cambridge, UK). After incubation with the primary antibody, the slides were rinsed with PBS 3 times and immunoperoxidase staining was performed using a biotinylated secondary antibody and the streptavidin-peroxidase complex (Novocastra), each step for $30 \mathrm{~min}$. Between the stages described above, the sections were carefully rinsed 3 times with PBS. Subsequently, the sections were incubated in a solution containing $5 \mathrm{mg}$ of diaminobenzidine (Gibco, Gaithersburg, MD, USA) dissolved in $5 \mathrm{ml}$ of PBS and $120 \mu \mathrm{l}$ of hydrogen peroxide. The DAB reaction was blocked with one wash of PBS followed by rinses in distilled water. The sections were then counterstained with Harris' hematoxylin for $1 \mathrm{~min}$, rinsed with distilled water, dehydrated with three absolute alcohol washes, immersed twice in xylene and mounted on Permount mounting medium (Merck, Darmstadt, Germany). All the steps were performed at room temperature. A normal tonsil, which is an accessible tissue containing highly proliferative cells in its germinal centers, was chosen as a positive control sample (28). A negative control sample was performed by replacing the specific primary antibody with $\mathrm{PBS}$.

Qualitative immunolabeling evaluation. Scoring and qualitative interpretation of immunohistochemical results were carried out by an experienced pathologist and data were classified as negative, discrete, moderate or intense immunolabeling. We considered the expression of BUBR1 to be low when the cells from the oral lesions were negative or showed discrete immunostaining. BUBR1 expression was classified as high when moderate or intense immunolabeling was observed.

Image acquisition and quantitative BUBRI evaluation. Positive cytoplasms were automatically quantified by a computer-assisted system (Image-Pro Plus-Cybernetics, MD, USA) consisting of a microscope, a digital camera and a software package. A mean of ten random microscope fields were selected in order to analyze 1,000 cytoplasm fields per biopsy in all patient sections. The images of the sections of 70 patients with oral carcinoma, 16 benign lesions and cervical lymph node biopsies were acquired on an electron photomicrograph and were then processed and analyzed by the software. For each slide, the digitized image segmentation was controlled interactively by the RGB color filter existing in the software program. The automatic cytoplasm count was determined and expressed as percentage.

$H P V$ detection and typing. Genomic DNA was obtained according to the protocol proposed by Bettini et al (29) modified. For generic HPV amplification by PCR the GP5+ (5'-TTT GTT ACT GTG GTA GAT ACT AC-3') and GP6 ${ }^{+}$ (3'-CTT ATA CTA AAT GTC AAA TAA AAA G-5') primers, which amplify a $150 \mathrm{bp}$ DNA fragment, were used (30). As an internal control of amplification and to evaluate the efficacy of DNA extraction, the amplification of generic HPV was performed together with primers for the human Bglobin gene $\left(\mathrm{PCO}^{+} 5^{5}-\mathrm{CTT}\right.$ CTG ACA CAA CTG TGT TCA CTA GC-3') and (PCO4+ 3'-CCA CTT GCA CCT ACT TCA ACA CCA CT-5') (31). The generic HPV-positive samples were amplified with specific primers for HPV16 (E7.667 5'-GAT GAA ATA GAT GGT CCA GC-3' and E7.774 3'-CGA AGC CAA CAC GCA TGT TTC G-5') and HPV18 (E7.696 5'-AAG AAA ACG ATG AAA TAG ATG GA-3' and E7.779 3'-ACA CAA CAT TCA CAC TTC GG-5') as described by Walboomers et al (32). The reaction mixture included $2 \mu 1$ of genomic DNA, $20 \mathrm{mM}$ deoxynucleoside triphosphate (Pharmacia, Uppsala, Sweden), $10 \mathrm{pmol} / \mu 1$ of each primer (IDT, IA, USA), 1.25 U Taq polymerase 
Table I. Clinical parameters of the 86 patients evaluated according to age, sex and tobacco and alcohol exposure.

\begin{tabular}{|c|c|c|c|c|c|}
\hline Variable & $\mathrm{OL}^{\mathrm{NM}} \mathrm{n}=16$ & $\mathrm{OSCC}^{\mathrm{IS}} \mathrm{n}=20$ & $\mathrm{OSCC}^{\mathrm{WT}} \mathrm{n}=27$ & $\mathrm{OSCC}^{\mathrm{W}} \mathrm{n}=23$ & Total $n=86$ \\
\hline Age $\mathrm{M} \pm \mathrm{SD}$ & $52.94 \pm 14.55$ & $54.45 \pm 11.51$ & $59.41 \pm 12.76$ & $58.43 \pm 13.25$ & $56.79 \pm 13.01$ \\
\hline \multicolumn{6}{|l|}{ Gender, n (\%) } \\
\hline Male & $10(62.5)$ & $18(90.0)$ & $21(77.8)$ & $22(95.6)$ & $71(82.6)$ \\
\hline Female & $6(37.5)$ & $2(10.0)$ & $6(22.2)$ & $1(4.4)$ & $15(17.4)$ \\
\hline \multicolumn{6}{|c|}{ Tabacco exposure, n (\%) } \\
\hline Yes & $6(37.5)$ & $20(100)$ & $21(77.8)$ & $22(95.6)$ & $69(80.2)^{\mathrm{a}}$ \\
\hline No & $6(37.5)$ & $0(0)$ & $6(22.2)$ & $1(4.4)$ & $13(15.1)^{\mathrm{a}}$ \\
\hline \multicolumn{6}{|c|}{ Alcohol consumption, $\mathrm{n}(\%)$} \\
\hline Yes & $3(18.8)$ & $14(70.0)$ & $19(70.4)$ & $21(91.3)$ & $57(66.3)^{\mathrm{a}}$ \\
\hline No & $8(50.0)$ & $6(30.0)$ & $8(29.6)$ & $2(8.7)$ & $24(27.9)^{\mathrm{a}}$ \\
\hline
\end{tabular}

$\mathrm{OL}^{\mathrm{NM}}$, non-malignant oral lesion; OSCC ${ }^{\mathrm{IS}}$, in situ oral squamous cell carcinoma; OSCC ${ }^{\mathrm{WT}}$, invasive oral squamous cell carcinoma without metastases; OSCC ${ }^{\mathrm{W}}$, invasive oral squamous cell carcinoma with metastases. ${ }^{a}$ No information was available about tobacco and alcohol exposure for four and five patients, respectively. M, mean; SD, standard deviation.

(Invitrogen, Brazil), $0.75 \mathrm{mM} \mathrm{MgCl}_{2}, 3.5 \mu \mathrm{l}$ of $10 \mathrm{X}$ buffer (Invitrogen, Brazil), and distilled deionized $\mathrm{H}_{2} \mathrm{O}$ to complete a total volume of $23 \mu \mathrm{l}$. The cycling conditions for almost all generic and HPV types consisted of an initial denaturation step at $94^{\circ} \mathrm{C}$ for $5 \mathrm{~min}$, followed by 40 cycles at $94^{\circ} \mathrm{C}$ for $1 \mathrm{~min}$, at $55^{\circ} \mathrm{C}$ for $1 \mathrm{~min}$, and at $72^{\circ} \mathrm{C}$ for $1 \mathrm{~min}$, with a final extension cycle of $72^{\circ} \mathrm{C}$ for $10 \mathrm{~min}$. PCR products were separated on $10 \%$ non-denaturing polyacrylamide gels followed by silver staining, as described by Sanguinetti et al (33). The positive PCR control was HPV-positive DNA collected from cervical samples. As a negative control, all PCR reagents were added to an Eppendorf tube containing no DNA sample.

Statistical analysis. The distributions of three clinical parameters were compared between the different groups by means of the two-sided Fisher's exact test $(2 \times 2$ contingency tables) with the aid of GraphPad InStat software, which was also used to estimate the odds ratio (OR) and its $95 \%$ confidence interval $(95 \% \mathrm{CI})$. Age, reported as arithmetic mean and standard deviation, was also compared between groups by means of the two-sided unpaired Student's t-test.

Qualitative differences in BUBR1 expression related to clinicopathological features in the groups were evaluated by means of the Fisher's exact test (in case of $2 \times 2$ tables) using the GraphPad InStat software or by an exact test that uses the Metropolis algorithm to obtain an unbiased estimate of the exact $p$-value and its standard error (in case of more complex RxC tables) using RXC software. For quantitative analysis, since the BUBR1 expression data passed the Kolmogorov-Smirnov normality test (KS), parametric analyses were performed using one-way ANOVA with the Tukey-Kramer multiple comparisons post test and the unpaired t-test with Welch correction. The correlation between $\mathrm{OSCC}^{\mathrm{W}}$ and LN was calculated using the Spearman rank correlation test.
The differences in the prevalence of HPV and HPV types in the different groups were evaluated by an exact test using RXC software and the correlation between BUBR1 expression and HPV prevalence was calculated by the Fisher's exact test (in case of $2 \times 2$ tables) using the GraphPad InStat software. The comparison of mean of BUBR 1 expression between the HPV-positive malignant groups was evaluated by the unpaired t-test with Welch correction and when the data did not pass the normality test, the Mann-Whitney test was used.

Analysis of survival time was performed using KaplanMeier curves and differences between curves were evaluated by the log-rank test using the GraphPad Prism version 4.00 for Windows. Cumulative survival was computed from the date of diagnosis or surgery to the documented date of follow-up or death. P-values were two-sided and the level of significance was set at $5 \%(\alpha=0.05)$.

\section{Results}

Oral squamous cell lesions and clinical parameters. A total of 86 cases of oral lesions were studied in 71 men and 15 women with a mean age of 56.79 years. Tobacco and alcohol exposure was a predominant habit in 80.2 and $66.3 \%$ of patients, respectively. Mean age and gender were quite homogeneous among the different groups studied. However, the group of non-malignant oral lesions (OL ${ }^{\mathrm{NM}}$ ) showed a different behavior compared to the other groups regarding tobacco and alcohol exposure (Table I).

Statistical analysis of the clinical parameters demonstrated that there more men had oral carcinomas as a whole, but especially in cases with metastasis, when compared with the non-malignant group. The frequency of tobacco and alcohol consumption was significantly higher in all carcinomas evaluated together than in benign lesions. The groups with in situ carcinomas and with metastasis also had signi- 
Table II. Clinical parameters of malignant versus non-malignant groups and among the different groups of oral squamous cell carcinoma.

\begin{tabular}{|c|c|c|c|c|}
\hline Variable & Age $^{a}$ & Gender $^{\mathrm{b}}$ & Tobacco exposure $^{\mathrm{b}}$ & Alcohol consumption $^{\mathrm{b}}$ \\
\hline $\mathrm{OSCC}^{\mathrm{IS}}$ vs. OL ${ }^{\mathrm{NM}}$ & $\mathrm{p}=0.7368$ & $\begin{array}{l}\mathrm{p}=0.1034 \\
\mathrm{OR}=5.400 \\
\mathrm{CI}(0.9128-31.947)\end{array}$ & $\begin{array}{l}\mathrm{p}=0.0010^{\mathrm{c}} \\
\mathrm{OR}=41.000 \\
\mathrm{CI}(2.022-831.32)\end{array}$ & $\begin{array}{l}\mathrm{p}=0.0309^{\mathrm{c}} \\
\mathrm{OR}=6.222 \\
\mathrm{CI}(1.212-31.950)\end{array}$ \\
\hline OSCC $^{\mathrm{WT}}$ vs. OL ${ }^{\mathrm{NM}}$ & $\mathrm{p}=0.1517$ & $\begin{array}{l}\mathrm{p}=0.3126 \\
\mathrm{OR}=2.100 \\
\mathrm{CI}(0.5392-8.179)\end{array}$ & $\begin{array}{l}\mathrm{p}=0.1331 \\
\mathrm{OR}=3.500 \\
\mathrm{CI}(0.8204-14.932)\end{array}$ & $\begin{array}{l}\mathrm{p}=0.0309^{\mathrm{c}} \\
\mathrm{OR}=6.222 \\
\mathrm{CI}(1.212-31.950)\end{array}$ \\
\hline $\mathrm{OSCC}^{\mathrm{W}}$ vs. OL $\mathrm{OL}^{\mathrm{NM}}$ & $\mathrm{p}=0.2382$ & $\begin{array}{l}\mathrm{p}=0.0127^{\mathrm{c}} \\
\mathrm{OR}=13.200 \\
\mathrm{CI}(1.397-124.69)\end{array}$ & $\begin{array}{l}\mathrm{p}=0.0033^{\mathrm{c}} \\
\mathrm{OR}=22.000 \\
\mathrm{CI}(2.201-219.87)\end{array}$ & $\begin{array}{l}\mathrm{p}=0.0003^{\mathrm{c}} \\
\mathrm{OR}=28.000 \\
\mathrm{CI}(3.919-200.03)\end{array}$ \\
\hline Malignant vs. OL ${ }^{\mathrm{NM}}$ & $\mathrm{p}=0.2432$ & $\begin{array}{l}\mathrm{p}=0.0296^{\mathrm{c}} \\
\mathrm{OR}=4.067 \\
\mathrm{CI}(1.188 \text { to } 13.925)\end{array}$ & $\begin{array}{l}\mathrm{p}=0.0027^{\mathrm{c}} \\
\mathrm{OR}=9.000 \\
\mathrm{CI}(2.275-35.603)\end{array}$ & $\begin{array}{l}\mathrm{p}=0.0020^{\mathrm{c}} \\
\mathrm{OR}=9.000 \\
\mathrm{CI}(2.133-37.977)\end{array}$ \\
\hline OSCC $^{\mathrm{WT}}$ vs. OSCC & $\mathrm{p}=0.1706$ & $\begin{array}{l}\mathrm{p}=0.4369 \\
\mathrm{OR}=0.3889 \\
\mathrm{CI}(0.06963-2.172)\end{array}$ & $\begin{array}{l}\mathrm{p}=0.0312^{\mathrm{c}} \\
\mathrm{OR}=0.08068 \\
\mathrm{CI}(0.0043-1.526)\end{array}$ & $\begin{array}{l}\mathrm{p}=1.0000 \\
\mathrm{OR}=1.018 \\
\mathrm{CI}(0.2876-3.603)\end{array}$ \\
\hline $\mathrm{OSCC}^{\mathrm{W}}$ vs. OSCCWT & $\mathrm{p}=0.7936$ & $\begin{array}{l}\mathrm{p}=0.1068 \\
\mathrm{OR}=6.286 \\
\mathrm{CI}(0.6962-56.750)\end{array}$ & $\begin{array}{l}\mathrm{p}=0.1068 \\
\mathrm{OR}=6.286 \\
\mathrm{CI}(0.6962-56.750)\end{array}$ & $\begin{array}{l}\mathrm{p}=0.0850 \\
\mathrm{OR}=4.421 \\
\mathrm{CI}(0.8326-23.475)\end{array}$ \\
\hline
\end{tabular}

$\mathrm{OL}^{\mathrm{NM}}$, non-malignant oral lesion; OSCC ${ }^{\mathrm{IS}}$, in situ oral squamous cell carcinoma; OSCC ${ }^{\mathrm{WT}}$, invasive oral squamous cell carcinoma without metastases; OSCCW ${ }^{\mathrm{W}}$ invasive oral squamous cell carcinoma with metastases. p, p-value; OR, odds ratio; CI, 95\% confidence interval. aUnpaired t-test; ${ }^{b}$ Fisher's exact test. ${ }^{c}$ Statistically significant.

ficantly more smoking and drinking patients than nonmalignant patients. The smoking habit was more frequent among patients with invasive carcinomas without metastasis only when compared with in situ carcinomas $(\mathrm{p}=0.0312)$ and alcohol consumption was also statistically more common among patients with invasive samples without metastases than in non-malignant ones (Table II).

BUBR1 qualitative expression and clinicopathological features. Immunolabeling of BUBR1 was classified as low and high expression. All samples of the $\mathrm{OL}^{\mathrm{NM}}$ group showed low expression, while in the malignant lesions (OSCC ${ }^{\mathrm{IS}}$, OSCC ${ }^{\mathrm{WT}}$ and $\mathrm{OSCC}^{\mathrm{W}}$ ) high expression was observed in 15/20 (75\%), $19 / 27(70 \%)$ and 18/23 (78\%) of them, respectively (Fig. 1). In this study, we observed only immunolabeling of BUBR 1 in the cell cytoplasm, as previously reported (28). Even in most cases showing high BUBR1 expression, the relationship between qualitative BUBR1 expression and clinicopathological features (location, TNM stage, treatment, recurrence and death) did not show a positive association, except regarding location when all malignant samples were analyzed together $(p=0.0078 \pm 0.0003)$. We observed that the profile of BUBR1 expression in the tongue was opposite to that in the gums. The tongue showed high expression in 28 out of 33 samples while the majority of guns showed low expression, as summarized in Table III. The immunostaining of cervical
LN biopsies with metastasis showed high expression in 15 $(65 \%)$ out of 23 lymph nodes.

Quantitative expression of BUBR1 in oral lesions. Similar to the qualitative evaluation of BUBR1 expression, quantitative analyses showed a significantly higher number of cells expressing BUBR1 in malignant oral lesions, but not in nonmalignant ones. Cervical metastatic lymph nodes presented quite similar expression, as observed in their respective invasive oral lesions (Fig. 2). Thus, multiple comparisons analysis showed a statistically significant difference between the OL ${ }^{\mathrm{NM}}$ group and the other groups studied, as shown in Table IV. Although the variance between $\mathrm{OSCC}^{\mathrm{W}}$ and their LN was not statistically significant by Wilcoxon matchedpairs analysis $(\mathrm{p}=0.1895)$, the correlation between OSCC ${ }^{\mathrm{W}}$ and LN ( $<<0.0001 ; \mathrm{r}=1.000)$ was significant.

Human papillomavirus detection and correlation with BUBRl expression. Of the 86 oral lesions evaluated, 79 (91.9\%) were positive for HPV. HPV DNA was also detected in $22 / 23(95.6 \%)$ lymph nodes, in $100 \%$ of the OSCC ${ }^{\mathrm{W}}$ group and in all lesions without carcinoma. With respect to viral type, HPV16 was detected in $11(13.9 \%)$ cases and in $4(17.4 \%)$ lymph nodes, and HPV18 was observed in $17(21.5 \%)$ lesions and in $4(17.4 \%)$ lymph nodes. Double infection with both types was found in two cases in the 

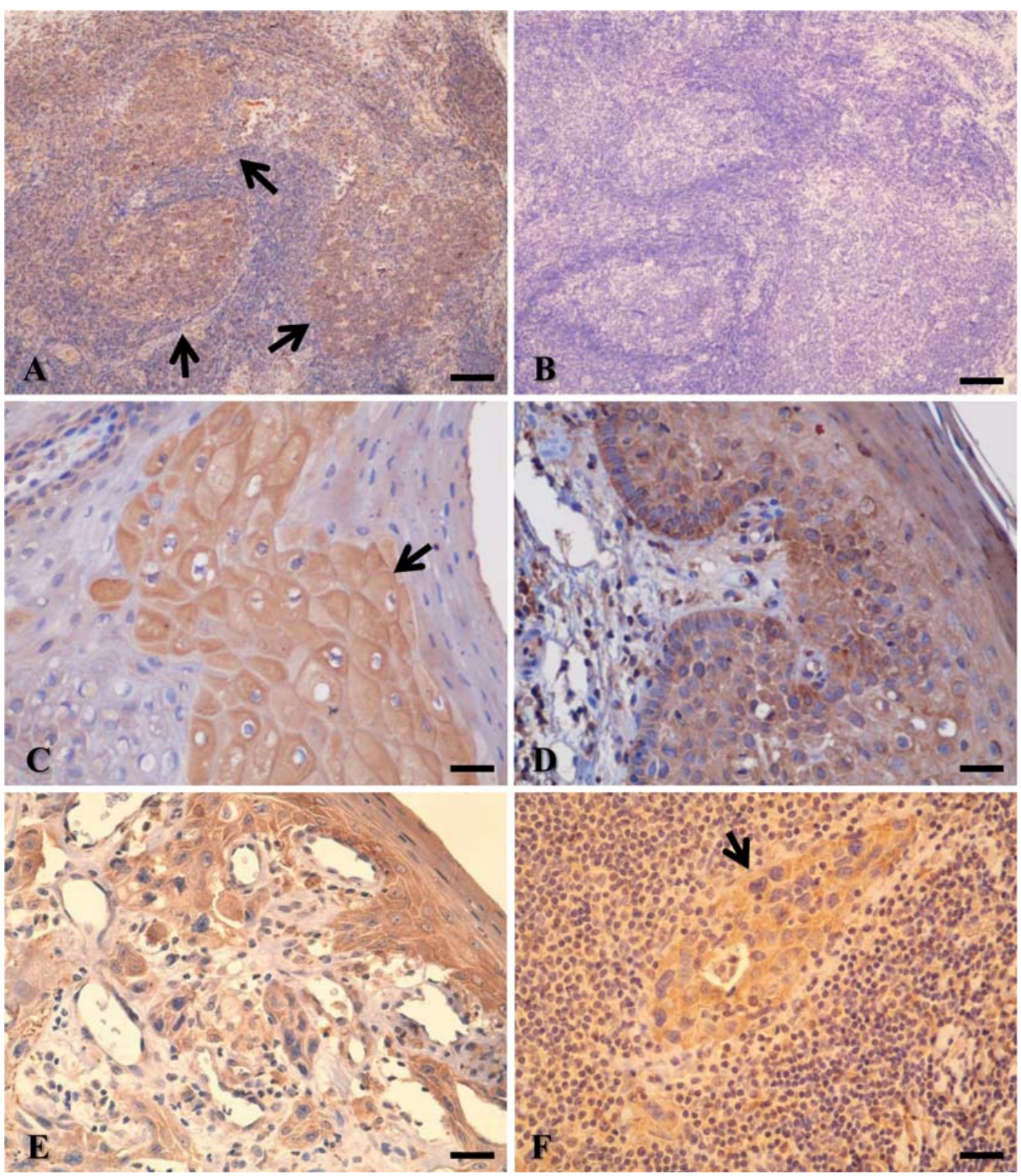

Figure 1. BUBR1 expression determined by immunohistochemistry. (A) BUBR1 expression in cells of germinal centers (arrows) of a normal tonsil used lesion negative for BUBR1, but with koilocytes expressing tas positive control; (B) absence of expression in a normal tonsil without the step of primary antibody incubation (negative control); (C) non-malignant oral he protein (arrow); (D) high expression of BUBR1 in oral carcinoma in situ; (E) invasive carcinoma with metastasis with high expression; (F) metastatic lymph node with high expression of BUBR1 in malignant cells (arrow) and diffuse immunolabeling in the surrounding lymphocytes.

$\mathrm{OSCC}^{\mathrm{WT}}$ group, in five cases of the $\mathrm{OSCC}^{\mathrm{W}}$ group, and in two lymph nodes. There was a significantly higher $(\mathrm{p}=0.000146)$ detection rate of HPV18 in the OSCC ${ }^{\mathrm{WT}}$ and $\mathrm{OSCC}^{\mathrm{W}}$ groups than in the OSCC ${ }^{\mathrm{IS}}$ and $\mathrm{OL}^{\mathrm{NM}}$ groups.

HPV was more prevalent $(76.2 \%)$ in the malignant cases with high BUBR1 immunolabeling. The number of HPV-negative cases was equal in samples with high or low expression of BUBR1. Interestingly, we also observed that in some cases presenting koilocytes (HPV-infected cells) the BUBR1 protein was expressed specifically in the cytoplasm of these cells, while in surrounding cells that had no characteristics of koilocytes, the expression was absent (Fig. 1C).

More HPV18 was found in carcinomas with high BUBR1 expression, but HPV type 16 and the cases with both
HPV types showed similar prevalence according to BUBR1 immunolabeling. Statistical analysis showed no significant association between the presence of HPV and qualitative BUBR1 expression, as summarized in Table V. Fifteen lymph nodes showed high expression of BUBR1. Of these, two were type 16 and three were type 18 . The other ten lymph nodes were neither 16 nor 18 types and therefore were considered as other types. Since all OL ${ }^{\mathrm{NM}}$ cases showed a low BUBR1 expression and HPV was found in all cases, this group was not considered for statistical analysis.

Considering only HPV-positive lesions, the comparison of the mean number of labeled cells from cases classified as high and low BUBR1 expression showed that the number of marker cells differed significantly in oral carcinomas with 
Table III. Correlation of qualitative BUBR1 expression with clinicopathological features in all OSCC samples.

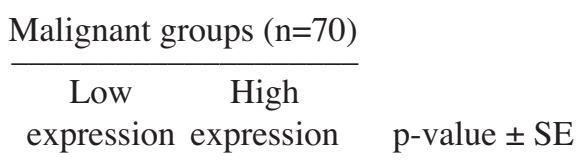

\begin{tabular}{|c|c|c|c|}
\hline \multicolumn{4}{|l|}{ Location } \\
\hline Tongue & 5 & 28 & $\mathrm{a}, \mathrm{d} p=0.0078 \pm 0.0003$ \\
\hline Lips & 3 & 9 & \\
\hline Mouth floor & 2 & 6 & \\
\hline Gum & 5 & 1 & \\
\hline Buccal mucosa & 0 & 5 & \\
\hline Retromolar area & 3 & 3 & \\
\hline \multicolumn{4}{|l|}{ TNM stage } \\
\hline Tis & 2 & 7 & \\
\hline T1-T2 & 12 & 29 & ${ }^{\mathrm{a}} \mathrm{p}=0.7944 \pm 0.0008$ \\
\hline T3-T4 & 4 & 16 & \\
\hline $\mathrm{Nx}$ & 7 & 15 & \\
\hline N0 & 4 & 14 & ${ }^{\mathrm{a}} \mathrm{p}=0.7793 \pm 0.0009$ \\
\hline N1-N3 & 7 & 23 & \\
\hline $\mathrm{Mx}$ & 17 & 50 & ${ }^{\mathrm{b}} \mathrm{p}=1.000$ \\
\hline M0 & 1 & 2 & \\
\hline \multicolumn{4}{|l|}{ Tumor treatment } \\
\hline Surgery & 6 & 15 & ${ }^{\mathrm{a}} \mathrm{p}=0.9704 \pm 0.0002$ \\
\hline \multicolumn{4}{|l|}{ Surgery plus } \\
\hline RTx and/or QTx & 8 & 25 & \\
\hline RTx and/or QTx & 3 & 10 & \\
\hline Other treatments ${ }^{c}$ & 1 & 2 & \\
\hline \multicolumn{4}{|l|}{ Recurrence } \\
\hline Yes & 8 & 22 & ${ }^{\mathrm{b}} \mathrm{p}=1.000$ \\
\hline No & 10 & 30 & \\
\hline \multicolumn{4}{|l|}{ Death } \\
\hline Yes & 3 & 22 & ${ }^{\mathrm{b}} \mathrm{p}=0.0850$ \\
\hline No & 15 & 30 & \\
\hline Total (n) & 18 & 52 & \\
\hline
\end{tabular}

$\mathrm{OL}^{\mathrm{NM}}$, non-malignant oral lesion; $\mathrm{OSCC}^{\mathrm{IS}}$, in situ oral squamous cell carcinoma; $\mathrm{OSCC}^{\mathrm{WT}}$, invasive oral squamous cell carcinoma without metastases; $\mathrm{OSCC}^{\mathrm{W}}$, invasive oral squamous cell carcinoma with metastases. LE, low expression; HE, high expression; SE, standard error. ${ }^{a} \mathrm{RXC}$ software (http://www.marksgeneticsoftware. net/rxc.htm). ${ }^{b}$ Fisher's exact test. ${ }^{\mathrm{c} O t h e r}$ treatments, phototherapy or treatment at another service. ${ }^{\mathrm{d}}$ Statistically significant.

metastasis, in metastatic lymph nodes and when all malignant cases were analyzed together. In invasive carcinomas without metastasis the difference between means of high and low expression was quite significant, as summarized in Table VI.

Survival analysis. After a median follow-up of 25 months, 25 of the 70 patients with malignant oral lesions had died. The estimated mean cumulative survival from the date of

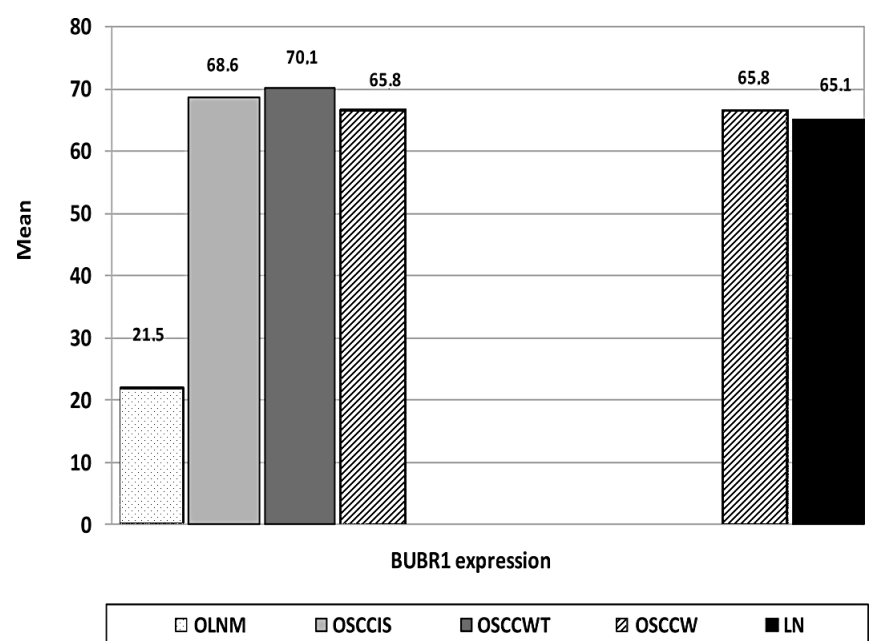

Figure 2. Quantitative BUBR1expression according to histological group.

Table IV. Immunoexpression of BUBR1 in malignant versus non-malignant oral lesions.

\begin{tabular}{|c|c|}
\hline Histological groups & p-value \\
\hline $\mathrm{OSCC}^{\mathrm{IS}}$ vs. OL ${ }^{\mathrm{NM}}$ & ${ }^{\mathrm{a}} \mathrm{p}<0.001^{\mathrm{c}}$ \\
\hline $\mathrm{OSCC}^{\mathrm{WT}}$ vs. OL ${ }^{\mathrm{NM}}$ & ${ }^{\mathrm{a}} \mathrm{p}<0.001^{\mathrm{c}}$ \\
\hline $\mathrm{OSCC}^{\mathrm{W}}$ vs. OL $\mathrm{OL}^{\mathrm{NM}}$ & ${ }^{\mathrm{a}} \mathrm{p}<0.001^{\mathrm{c}}$ \\
\hline $\mathrm{OSCC}^{\mathrm{WT}}$ vs. OSCC ${ }^{\mathrm{IS}}$ & ${ }^{\mathrm{a}} \mathrm{p}>0.05$ \\
\hline $\mathrm{OSCC}^{\mathrm{W}}$ vs. OSCC ${ }^{\mathrm{IS}}$ & ${ }^{\mathrm{a}} \mathrm{p}>0.05$ \\
\hline $\mathrm{OSCC}^{\mathrm{W}}$ vs. OSCC ${ }^{\mathrm{WT}}$ & ${ }^{\mathrm{a}} \mathrm{p}>0.05$ \\
\hline Malignant vs. OL ${ }^{\mathrm{NM}}$ & ${ }^{b} \mathrm{p}<0.001^{\mathrm{c}}$ \\
\hline
\end{tabular}

$\mathrm{OL}^{\mathrm{NM}}$, non-malignant oral lesion; $\mathrm{OSCC}^{\mathrm{IS}}$, in situ oral squamous cell carcinoma; OSCC ${ }^{\mathrm{IS}}$, in situ oral squamous cell carcinoma; OSCCWT, invasive oral squamous cell carcinoma without metastases; OSCC ${ }^{\mathrm{W}}$, invasive oral squamous cell carcinoma with

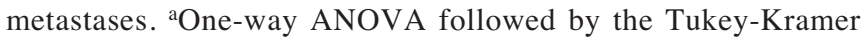
post-test $(\mathrm{p}<0.0001)$. ${ }^{b}$ Unpaired t-test with Welch correction $(\mathrm{p}<0.0001)$. ${ }^{\mathrm{c}}$ Statistically significant.

diagnosis was 24 months for patients with high BUBR1 expression and 28 months for patients with low expression. Thirty of 70 oral carcinomas from the in situ, with and without metastasis groups had recurrence within a mean period of 13.5 months after the first diagnosis. None of the 16 patients without oral carcinoma died or presented malignant lesions during a median follow-up of 24 months and all of them showed low BUBR1 expression. Patients with malignant samples with high BUBR1 expression showed a significantly shorter cumulative survival than patients with malignant samples with low expression (logrank test, $\mathrm{p}=0.0479$ ), as described in Fig. 3 .

No significant difference was observed between the cumulative survival curves for patients with metastatic LN with high and low BUBR1 expression. The comparison of cumulative survival curves for HPV-positive and HPV- 
Table V. BUBR1 expression in malignant oral lesions according to prevalence of HPV and types.

\begin{tabular}{|c|c|c|c|c|c|}
\hline BUBR1 expression & $\begin{array}{c}\mathrm{HPV}^{+}(\mathrm{n}=63) \\
(\%)\end{array}$ & $\begin{array}{c}\mathrm{HPV}^{-}(\mathrm{n}=7) \\
(\%)\end{array}$ & $\begin{array}{c}\text { HPV16 }(\mathrm{n}=9) \\
(\%)\end{array}$ & $\begin{array}{c}\text { HPV18 }(\mathrm{n}=17) \\
(\%)\end{array}$ & $\begin{array}{c}\text { HPV 16/18 }(\mathrm{n}=7) \\
(\%)\end{array}$ \\
\hline High & $48(76.2)$ & $4(57.1)$ & $5(55.6)$ & $13(76.5)$ & $4(57.1)$ \\
\hline Low & $15(23.8)$ & $3(42.9)$ & $4(44.4)$ & $4(23.5)$ & $3(42.9)$ \\
\hline p-value & \multicolumn{2}{|c|}{0.3626} & 0.1983 & 1.0000 & 0.3423 \\
\hline
\end{tabular}

Fisher's exact test.

Table VI. BUBR1 expression in HPV-positive cases.

\begin{tabular}{|c|c|c|c|}
\hline & High expression & Low expression & \\
\hline $\mathrm{HPV}^{+}$cases & Mean \pm SD & Mean \pm SD & p-value \\
\hline $\operatorname{OSCC}^{\mathrm{IS}}(\mathrm{n}=15)$ & $70.3 \pm 2.874$ & $62.9 \pm 2.276$ & ${ }^{\mathrm{a}} \mathrm{p}=0.2945$ \\
\hline $\operatorname{OSCC}^{\mathrm{WT}}(\mathrm{n}=25)$ & $72.1 \pm 1.876$ & $64.2 \pm 3.166$ & ${ }^{\mathrm{b}} \mathrm{p}=0.0558$ \\
\hline $\operatorname{OSCC}^{\mathrm{W}}(\mathrm{n}=23)$ & $68.9 \pm 2.392$ & $54.3 \pm 4.463$ & ${ }^{\mathrm{b}} \mathrm{p}=0.0278$ \\
\hline Malignant $(n=63)$ & $70.5 \pm 1.333$ & $60.6 \pm 2.343$ & ${ }^{\mathrm{b}} \mathrm{p}=0.0014$ \\
\hline $\mathrm{LN}(\mathrm{n}=23)$ & $69.6 \pm 1.565$ & $56.5 \pm 2.570$ & ${ }^{\mathrm{b}} \mathrm{p}=0.0010^{\circ}$ \\
\hline
\end{tabular}

$\mathrm{OSCC}^{\mathrm{IS}}$, in situ oral squamous cell carcinoma; OSCC ${ }^{\mathrm{WT}}$, invasive oral squamous cell carcinoma without metastases; OSCC ${ }^{\mathrm{W}}$, invasive

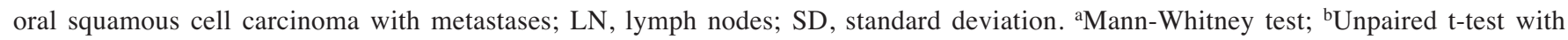
Welch correction; 'Statistically significant.

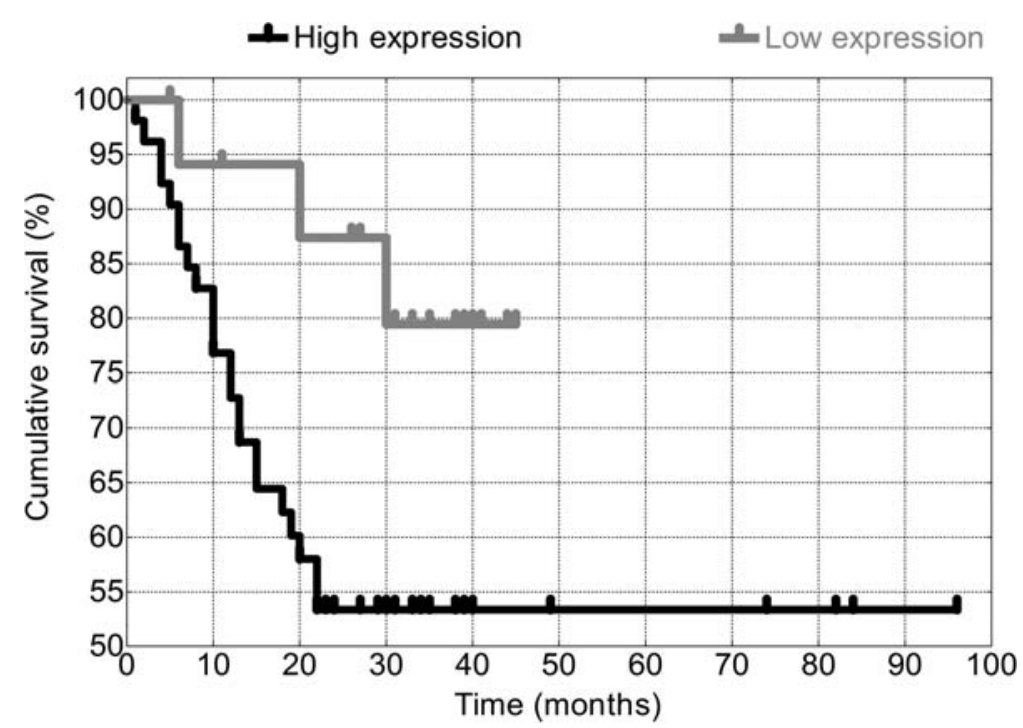

Figure 3. Cumulative survival of 70 oral malignant lesions with distinct profiles of BUBR1 expression. The difference between the curves was significant $(\mathrm{p}=0.0479)$.

negative malignant cases showed no significant difference $(\mathrm{p}=0.5315)$. However, patients who presented HPV DNA in their samples had shorter survival than HPV DNAnegative patients. No significant difference in survival curves was observed according to the viral type in oral carcinomas, but patients with HPV18 infection showed the shortest survival, followed by HPV16 and the other types that were not classified. The survival of patients with the presence of HPV16 in lymph nodes was longer than the survival for of patients with HPV18, and patients with lymph nodes 
containing other viral types presented the shortest overall survival (data not shown).

\section{Discussion}

Similar to previous studies in developing nations, the mean age of our patients including the group of non-malignant lesions was $56.79 \pm 1.40$ years $(34,35)$. In this study, tobacco exposure was observed in $90 \%$ of the patients with OSCC, ranging from 77.8 to $100 \%$ intergroup. The profile of our patient regarding tobacco consumption was similar to those detected in some previous studies even in developed countries $(9,35,36)$, but other authors reported a different prevalence $(50-65.5 \%)$ of smoking patients $(1,34,37)$. The percent of smokers in $\mathrm{OL}^{\mathrm{NM}}$ was similar to the control group of a study with young adults performed by Rodriguez et al (38).

Undoubtedly important in OSCC, alcohol increases the risk of OSCC, but how the intensity of alcohol intake determines this risk is unclear. Most of our patients with OSCC (77\%; range: 70-91.3\%) were also alcohol drinkers, in agreement with previous findings in Hungary $(75.5 \%)$ (37), Brazil (80.9\%) and the USA (69.8\%) (35), but in contrast to some studies that found a lower prevalence of alcohol consumption $(1,9,34,38,39)$.

HPV has been associated with increased risk of oral cancer regardless of tobacco and alcohol exposure, especially the high-risk types 16 and $18(6,7,40)$. In this study, $90 \%$ of OSCC and $100 \%$ of OL ${ }^{\mathrm{NM}}$ were HPV positive. A Chinese study on 73 OSCC found a 74\% prevalence of HPV (41), while Bouda et al (13) and Furrer et al (12), in studies on smaller samples, detected 95 and $100 \%$ HPV positivity, respectively. The results of the present investigation agree with the latter two studies. However, most studies report a range of viral prevalence from 20 to $43 \%$ (42-45). HPV prevalence varies from 0 to $55 \%$ in normal oral samples and is more than $80 \%$ in hyperplasias and dysplastic lesions $(8,14,41)$. Our samples without cancer were diagnosed as traumatic fibromas, and therefore the high prevalence of HPV in our group without cancer must be a regional characteristic. Brazilian $(44,46)$ and Italian (14) studies of OSCC have reported a higher prevalence of HPV18 than HPV16, which agrees with our results, but does not agree with the majority of studies conducted in other countries where HPV16 is the most prevalent type in oral malignant lesions $(16,41,45)$. Only the OSCC ${ }^{\mathrm{WT}}$ and OSCCW ${ }^{\mathrm{W}}$ groups presented co-infection with both viral types, representing $10 \%$ of our malignant oral lesions, which is consistent with data reported by other authors $(41,44,47)$.

Studies on mutations in the BUBR1 gene, its expression by mRNA, IHC and Northern blotting have been performed in other types of samples such as adrenocortical tumors (48), breast cancer (25), lung cancer (49), thyroid tumors (50), glioblastomas (51), and hepatocellular carcinoma (52). Our findings of high BUBR1 expression in OSCC, from 70 to $78 \%$ of cases intergroup, were similar to the results reported by Grabsch et al (26) that showed BUBR1 mRNA overexpression in $68 \%$ out of 43 gastric carcinomas, although without a correlation with DNA ploidy or histopathological parameters. We observed no significant association of
BUBR1 expression and clinicopathological features, except for location. On the other hand, Yamamoto et al (23) and Burum-Auensen et al (53) observed BUBR1 overexpression in bladder cancer and ulcerative colitis-associated colorectal cancer which was correlated with higher histological grade, advanced pathological stage, tumor recurrence and disease progression.

It has long been known that several virus-encoded proteins, including HPV E6/E7, induce aneuploidy and genomic instability by disrupting mitotic checkpoint controls. Some reported targets of these viral proteins are BUB1, BUBR1, MAD1 and MAD2 (22,54-56). To our knowledge, there have been no studies evaluating BUBR1 expression in OSCC associated with HPV infection by IHC. In our study, HPV was more prevalent in the samples of oral carcinomas with high BUBR1expression and in some cases that presented koilocytes, the expression of BUBR1 was observed only in the cytoplasm of these cells. This co-localization of HPV and BUBR1 immunolabeling may suggest some kind of interaction between the virus and BUBR1 protein. However, further studies analyzing this possibility in more detail could contribute to the understanding of the probable roles of HPV in carcinogenesis and in genomic instability.

Our malignant samples with high BUBR1 expression showed significantly shorter survival. Yamamoto et al (23) analyzed BUBR1 by IHC in 104 human urothelial bladder carcinomas and found similar results. The presence of HPV in our malignant samples was associated with shorter cumulative survival, which is not consistent with Chien et al (57) and Armas et al (58), who reported higher survival rates in HPV-positive patients with tonsil and head and neck carcinomas, respectively. The cause of this disagreement could be the fact that we found a higher prevalence of HPV in malignant cases than reported in other studies, or the variability of the sites evaluated in each study. In addition, the survival curves for HPV-positive Brazilian floor of the mouth carcinomas reported by Simonato et al (39) were similar to ours.

It is known that BUBR1 interacts with and phosphorylates p53 (59), which is degraded by the HPV E6 oncoprotein $(60,61)$. Thus, BUBR1 overexpression in our samples of oral carcinomas could be some compensatory response due to the probable competition binding of HPV oncoproteins to proteins at the mitotic checkpoint. According to our findings, the presence of HPV in oral mucosa with malignant lesions could induce deregulation of the expression of BUBR1, which is a key protein of the mitotic checkpoint. In addition, the overexpression of BUBR1 and the presence of HPV DNA, especially the high-risk type 18 , were associated with shorter survival of patients with oral carcinoma. Since the relation between viruses and BUBR1 is a recent issue, our study brings new insights into the understanding of the role of HPV in oral carcinogenesis.

\section{Acknowledgements}

The present study was supported by Conselho Nacional de Desenvolvimento Científico e Tecnológico (National Council of Scientific and Technological Development), CNPq, a Brazilian research funding organization. We thank Ana 
Maria da Rocha for excellent technical assistance and Dr Celso $\mathrm{T}$ Mendes-Junior for contributions to the statistical analyses.

\section{References}

1. Arduino PG, Carrozzo M, Chiecchio A, Broccoletti R, Tirone F Borra E, Bertolusso G and Gandolfo S: Clinical and histopathologic independent prognostic factors in oral squamous cell carcinoma: a retrospective study of 334 cases. J Oral Maxillofac Surg 66: 1570-1579, 2008.

2. Scully $\mathrm{C}$ and Bagan J: Oral squamous cell carcinoma: overview of current understanding of aetiopathogenesis and clinical implications. Oral diseases: doi:10.1111/j.1601-0825. 2009.01563.x, 2009.

3. Ferlay J, Bray F, Pisani P and Parkin DM: GLOBOCAN 2002: Cancer Incidence, Mortality and Prevalence Worldwide. IARCPress, Lyon, 2004.

4. INCA, Instituto Nacional de Câncer: Estimativas 2008: Incidência de Câncer no Brasil. Rio de Janeiro, p94, 2007.

5. Goldenberg D, Brooksby C and Hollenbeak CS: Age as a determinant of outcomes for patients with oral cancer. Oral Oncol 45: e57-e61, 2009

6. Massano J, Regateiro FS, Januario G and Ferreira A: Oral squamous cell carcinoma: review of prognostic and predictive factors. Oral Surg Oral Med Oral Pathol Oral Radiol Endod 102: 67-76, 2006.

7. Andrews E, Seaman WT and Webster-Cyriaque J: Oropharyngeal carcinoma in non-smokers and non-drinkers: a role for HPV. Oral Oncol 45: 486-491, 2009.

8. Llamas-Martinez S, Esparza-Gomez G, Campo-Trapero J, Cancela-Rodriguez P, Bascones-Martinez A, Moreno-Lopez LA, Garcia-Nunez JA and Cerero-Lapiedra R: Genotypic determination by PCR-RFLP of human papillomavirus in normal oral mucosa, oral leukoplakia and oral squamous cell carcinoma samples in Madrid (Spain). Anticancer Res 28: 3733-3741, 2008.

9. Wunsch-Filho V: The epidemiology of oral and pharynx cancer in Brazil. Oral Oncol 38: 737-746, 2002.

10. Termine N, Panzarella V, Falaschini S, Russo A, Matranga D, Lo Muzio L and Campisi G: HPV in oral squamous cell carcinoma vs head and neck squamous cell carcinoma biopsies: a meta-analysis (1988-2007). Ann Oncol 19: 1681-1690, 2008.

11. Herrero R, Castellsague X, Pawlita M, Lissowska J, Kee F, Balaram P, Rajkumar T, Sridhar H, Rose B, Pintos J, Fernandez L, Idris A, Sanchez MJ, Nieto A, Talamini R, Tavani A, Bosch FX, Reidel U, Snijders PJ, Meijer CJ, Viscidi R, Munoz N and Franceschi S: Human papillomavirus and oral cancer: the International Agency for Research on Cancer multicenter study. J Natl Cancer Inst 95: 1772-1783, 2003.

12. Furrer VE, Benitez MB, Furnes M, Lanfranchi HE and Modesti NM: Biopsy vs. superficial scraping: detection of human papillomavirus $6,11,16$, and 18 in potentially malignant and malignant oral lesions. J Oral Pathol Med 35: 338-344, 2006.

13. Bouda M, Gorgoulis VG, Kastrinakis NG, Giannoudis A, Tsoli E, Danassi-Afentaki D, Foukas P, Kyroudi A, Laskaris G, Herrington CS and Kittas C: 'High risk' HPV types are frequently detected in potentially malignant and malignant oral lesions, but not in normal oral mucosa. Mod Pathol 13: 644-653, 2000

14. Giovannelli L, Campisi G, Lama A, Giambalvo O, Osborn J, Margiotta V and Ammatuna P: Human papillomavirus DNA in oral mucosal lesions. J Infec Dis 185: 833-836, 2002.

15. Luo CW, Roan CH and Liu CJ: Human papillomaviruses in oral squamous cell carcinoma and pre-cancerous lesions detected by PCR-based gene-chip array. Int J Oral Maxillofac Surg 36: $153-158,2007$

16. Sugiyama M, Bhawal UK, Dohmen T, Ono S, Miyauchi M and Ishikawa T: Detection of human papillomavirus-16 and HPV-18 DNA in normal, dysplastic, and malignant oral epithelium. Oral Surg Oral Med Oral Pathol Oral Radiol Endod 95: 594-600, 2003.

17. Lavia P, Mileo AM, Giordano A and Paggi MG: Emerging roles of DNA tumor viruses in cell proliferation: new insights into genomic instability. Oncogene 22: 6508-6516, 2003.

18. Reshmi SC, Saunders WS, Kudla DM, Ragin CR and Gollin SM: Chromosomal instability and marker chromosome evolution in oral squamous cell carcinoma. Genes Chromosomes Cancer 41: 38-46, 2004.
19. Saunders WS, Shuster M, Huang X, Gharaibeh B, Enyenihi AH, Petersen I and Gollin SM: Chromosomal instability and cytoskeletal defects in oral cancer cells. Proc Natl Acad Sci USA 97: 303-308, 2000

20. Reing JE, Gollin SM and Saunders WS: The occurrence of chromosome segregational defects is an intrinsic and heritable property of oral squamous cell carcinoma cell lines. Cancer Genet Cytogenet 150: 57-61, 2004.

21. Rao CV, Yamada HY, Yao Y and Dai W: Enhanced genomic instabilities caused by deregulated microtubule dynamics and chromosome segregation: a perspective from genetic studies in mice. Carcinogenesis (In press).

22. Kim S, Park SY, Yong H, Famulski JK, Chae S, Lee JH, Kang CM, Saya H, Chan GK and Cho H: HBV X protein targets hBubR1, which induces dysregulation of the mitotic checkpoint. Oncogene 27: 3457-3464, 2008

23. Yamamoto Y, Matsuyama H, Chochi Y, Okuda M, Kawauchi S, Inoue R, Furuya T, Oga A, Naito K and Sasaki K: Overexpression of BUBR 1 is associated with chromosomal instability in bladder cancer. Cancer Genet Cytogenet 174: 4247, 2007.

24. Shigeishi H, Yoneda S, Taki M, Nobumori T, Ohta K, Higashikawa K, Yasui W and Kamata N: Correlation of human Bub1 expression with tumor-proliferating activity in salivary gland tumors. Oncol Rep 15: 933-938, 2006.

25. Yuan B, Xu Y, Woo JH, Wang Y, Bae YK, Yoon DS, Wersto RP, Tully E, Wilsbach $\mathrm{K}$ and Gabrielson E: Increased expression of mitotic checkpoint genes in breast cancer cells with chromosomal instability. Clin Cancer Res 12: 405-410, 2006.

26. Grabsch H, Takeno S, Parsons WJ, Pomjanski N, Boecking A, Gabbert HE and Mueller W: Overexpression of the mitotic checkpoint genes BUB1, BUBR1, and BUB3 in gastric cancerassociation with tumour cell proliferation. J Pathol 200: 16-22, 2003.

27. Ying B and Wold WS: Adenovirus ADP protein (E3-11.6K), which is required for efficient cell lysis and virus release, interacts with human MAD2B. Virology 313: 224-234, 2003.

28. Burum-Auensen E, De Angelis PM, Schjolberg AR, Kravik KL, Aure $M$ and Clausen OP: Subcellular localization of the spindle proteins Aurora A, Mad2, and BUBR1 assessed by immunohistochemistry. J Histochem Cytochem 55: 477-486, 2007

29. Bettini JS, Soares EG, Duarte G, Simoes RT and Simoes AL: PCR diagnosis of HPV in cervical biopsies of CIN and invasive neoplasia formerly diagnosed as HPV negative. Acta Cytol 47: 545-549, 2003

30. De Roda Husman AM, Walboomers JM, van den Brule AJ, Meijer CJ and Snijders PJ: The use of general primers GP5 and GP6 elongated at their 3' ends with adjacent highly conserved sequences improves human papillomavirus detection by PCR. J Gen Virol 76 (Pt 4): 1057-1062, 1995

31. Saiki RK, Scharf S, Faloona F, Mullis KB, Horn GT, Erlich HA and Arnheim N: Enzymatic amplification of beta-globin genomic sequences and restriction site analysis for diagnosis of sickle cell anemia. Science (New York) 230: 1350-1354, 1985.

32. Walboomers JM, Jacobs MV, Manos MM, Bosch FX, Kummer JA, Shah KV, Snijders PJ, Peto J, Meijer CJ and Munoz N: Human papillomavirus is a necessary cause of invasive cervical cancer worldwide. J Pathol 189: 12-19, 1999.

33. Sanguinetti CJ, Dias Neto E and Simpson AJ: Rapid silver staining and recovery of PCR products separated on polyacrylamide gels. Biotechniques 17: 914-921, 1994.

34. Choi KK, Kim MJ, Yun PY, Lee JH, Moon HS, Lee TR and Myoung H: Independent prognostic factors of 861 cases of oral squamous cell carcinoma in Korean adults. Oral Oncol 42: 208-217, 2006

35. Carvalho AL, Singh B, Spiro RH, Kowalski LP and Shah JP: Cancer of the oral cavity: a comparison between institutions in a developing and a developed nation. Head Neck 26: 31-38, 2004.

36. Ghoshal S, Mallick I, Panda N and Sharma SC: Carcinoma of the buccal mucosa: analysis of clinical presentation, outcome and prognostic factors. Oral Oncol 42: 533-539, 2006.

37. Nemes JA, Redl P, Boda R, Kiss C and Marton IJ: Oral cancer report from Northeastern Hungary. Pathol Oncol Res 14: 85-92, 2008.

38. Rodriguez T, Altieri A, Chatenoud L, Gallus S, Bosetti C, Negri E, Franceschi S, Levi F, Talamini R and La Vecchia C: Risk factors for oral and pharyngeal cancer in young adults. Oral Oncol 40: 207-213, 2004. 
39. Simonato LE, Garcia JF, Sundefeld ML, Mattar NJ, Veronese LA and Miyahara GI: Detection of HPV in mouth floor squamous cell carcinoma and its correlation with clinicopathologic variables, risk factors and survival. J Oral Pathol Med 37: 593$598,2008$.

40. Nair S and Pillai MR: Human papillomavirus and disease mechanisms: relevance to oral and cervical cancers. Oral Dis 11: 350-359, 2005.

41. Zhang ZY, Sdek P, Cao J and Chen WT: Human papillomavirus type 16 and 18 DNA in oral squamous cell carcinoma and normal mucosa. Int J Oral Maxillofacial Surg 33: 71-74, 2004.

42. Ostwald C, Rutsatz K, Schweder J, Schmidt W, Gundlach K and Barten M: Human papillomavirus 6/11, 16 and 18 in ora carcinomas and benign oral lesions. Med Microbiol Immunol 192: 145-148, 2003

43. Ritchie JM, Smith EM, Summersgill KF, Hoffman HT, Wang D, Klussmann JP, Turek LP and Haugen TH: Human papillomavirus infection as a prognostic factor in carcinomas of the oral cavity and oropharynx. Int J Cancer 104: 336-344, 2003.

44. Oliveira MC, Soares RC, Pinto LP, Souza LB, Medeiros SR and Costa Ade L: High-risk human papillomavirus (HPV) is not associated with p53 and bcl-2 expression in oral squamous cell carcinomas. Auris Nasus Larynx 36: 450-456, 2009.

45. Anaya-Saavedra G, Ramirez-Amador V, Irigoyen-Camacho ME Garcia-Cuellar CM, Guido-Jimenez M, Mendez-Martinez R and Garcia-Carranca A: High association of human papillomavirus infection with oral cancer: a case-control study. Arch Med Res 39: 189-197, 2008

46. Soares RC, Oliveira MC, de Souza LB, Costa Ade L and Pinto LP: Detection of HPV DNA and immunohistochemical expression of cell cycle proteins in oral carcinoma in a population of Brazilian patients. J Appl Oral Sci 16: 340-344, 2008.

47. Nagpal JK, Patnaik S and Das BR: Prevalence of high-risk human papilloma virus types and its association with P53 codon 72 polymorphism in tobacco addicted oral squamous cell carcinoma (OSCC) patients of Eastern India. Int J Cancer 97: 649$653,2002$.

48. De Reynies A, Assie G, Rickman DS, Tissier F, Groussin L, Rene-Corail F, Dousset B, Bertagna X, Clauser E and Bertherat J: Gene expression profiling reveals a new classification of adrenocortical tumors and identifies molecular predictors of malignancy and survival. J Clin Oncol 27: 1108-1115, 2009.

49. Haruki N, Saito H, Harano T, Nomoto S, Takahashi T, Osada H, Fujii Y and Takahashi T: Molecular analysis of the mitotic checkpoint genes BUB1, BUBR1 and BUB3 in human lung cancers. Cancer Lett 162: 201-205, 2001.
50. Ouyang B, Knauf JA, Ain K, Nacev B and Fagin JA: Mechanisms of aneuploidy in thyroid cancer cell lines and tissues: evidence for mitotic checkpoint dysfunction without mutations in BUB1 and BUBR1. Clin Endocrinol 56: 341-350, 2002.

51. Reis RM, Nakamura M, Masuoka J, Watanabe T, Colella S, Yonekawa Y, Kleihues $\mathrm{P}$ and Ohgaki $\mathrm{H}$ : Mutation analysis of hBUB1, hBUBR1 and hBUB3 genes in glioblastomas. Acta Neuropathol 101: 297-304, 2001

52. Saeki A, Tamura S, Ito N, Kiso S, Matsuda Y, Yabuuchi I, Kawata S and Matsuzawa Y: Frequent impairment of the spindle assembly checkpoint in hepatocellular carcinoma. Cancer 94: 2047-2054, 2002.

53. Burum-Auensen E, Deangelis PM, Schjolberg AR, Roislien J, Andersen SN and Clausen OP: Spindle proteins Aurora A and BUB1B, but not Mad2, are aberrantly expressed in dysplastic mucosa of patients with longstanding ulcerative colitis. J Clin Pathol 60: 1403-1408, 2007.

54. Cotsiki M, Lock RL, Cheng Y, Williams GL, Zhao J, Perera D, Freire R, Entwistle A, Golemis EA, Roberts TM, Jat PS and Gjoerup OV: Simian virus 40 large T antigen targets the spindle assembly checkpoint protein Bub1. Proc Natl Acad Sci USA 101: 947-952, 2004.

55. Jin DY, Spencer F and Jeang KT: Human T cell leukemia virus type 1 oncoprotein Tax targets the human mitotic checkpoint protein MAD1. Cell 93: 81-91, 1998.

56. Pan SH, Tai CC, Lin CS, Hsu WB, Chou SF, Lai CC, Chen JY, Tien HF, Lee FY and Wang WB: Epstein-Barr virus nuclear antigen 2 disrupts mitotic checkpoint and causes chromosomal instability. Carcinogenesis 30: 366-375, 2009.

57. Chien CY, Su CY, Fang FM, Huang HY, Chuang HC, Chen CM and Huang CC: Lower prevalence but favorable survival for human papillomavirus-related squamous cell carcinoma of tonsil in Taiwan. Oral Oncol 44: 174-179, 2008.

58. Armas GL, Su CY, Huang CC, Fang FM, Chen CM and Chien CY: The impact of virus in N3 node dissection for head and neck cancer. Eur Arch Otorhinolaryngol 265: 1379-1384, 2008.

59. Ha GH, Baek KH, Kim HS, Jeong SJ, Kim CM, McKeon F and Lee CW: p53 activation in response to mitotic spindle damage requires signaling via BubR1-mediated phosphorylation. Cancer Res 67: 7155-7164, 2007.

60. Mammas IN, Sourvinos G, Giannoudis A and Spandidos DA: Human papilloma virus (HPV) and host cellular interactions. Pathol Oncol Res 14: 345-354, 2008.

61. Narisawa-Saito M and Kiyono T: Basic mechanisms of highrisk human papillomavirus-induced carcinogenesis: roles of E6 and E7 proteins. Cancer Sci 98: 1505-1511, 2007. 